\title{
Utilization of iron/organic ligand complexes by marine bacterioplankton
}

\author{
Richard S. Weaver, David L. Kirchman, David A. Hutchins* \\ College of Marine Studies, University of Delaware, 700 Pilottown Rd., Lewes, Delaware 19958, USA
}

\begin{abstract}
Nearly all of the dissolved iron in the ocean is bound in very strong organic complexes, but how heterotrophic bacteria obtain Fe from these uncharacterized natural ligands is not understood. We examined Fe uptake from model ligand $/{ }^{55} \mathrm{Fe}$ complexes by cultures of gamma and alpha marine proteobacteria grown under Fe-replete and Fe-limited conditions, and by natural bacterioplankton communities from the Sargasso Sea and California upwelling region. Model chelators included siderophores and porphyrins chosen to represent the possible structures of the unknown natural ligands. Complexed-Fe uptake was compared to uptake of Fe added in inorganic form. In all cases, the Fe-stressed cultures had higher uptake rates than the Fe-replete bacteria. The gamma proteobacterium Vibrio natriegens was best able to use siderophore-bound $\mathrm{Fe}$, especially from the catecholate siderophore enterobactin and the dihydroxamate rhodotorulic acid, but had very little success at utilizing porphyrin-bound Fe. In contrast, the alpha proteobacterium IRI-16 could use very little of the Fe bound to any of the model ligands in comparison to iron added in inorganic form. We observed variable degrees of Fe availability relative to ligand structure in natural communities. In some cases, Fe uptake by the prokaryotic size-class was most efficient from siderophores; in other cases, porphyrin-bound iron was more available. To better understand organically-bound Fe utilization by natural bacterioplankton communities, further studies combining ligand bioavailability measurements with detailed analyses of bacterioplankton community composition are needed.
\end{abstract}

KEY WORDS: Iron limitation · Iron uptake · Organic ligands · Iron complexation · Marine proteobacteria Resale or republication not permitted without written consent of the publisher

\section{INTRODUCTION}

It is now well documented that Fe limits phytoplankton growth in HNLC (high nutrient, low chlorophyll) regions of the worlds oceans (Martin \& Fitzwater 1988, Martin \& Gordon 1988, Price et al. 1994, De Baar et al. 1995, Coale et al. 1996, Hutchins \& Bruland 1998) and that up to $99.9 \%$ of the dissolved Fe in the oceans is bound to strong organic ligands (Gledhill \& van den Berg 1994, Rue \& Bruland 1995, Wu \& Luther 1995). The role that heterotrophic bacteria play in the acquisition and cycling of Fe is, however, much less understood. Bacterial growth can be either directly or indirectly stimulated by Fe additions in Antarctic (Pakulski et al. 1996, Boyd et al. 2000, Church et al. 2000) and sub-Antarctic waters (Hutchins et al. 2001), in the subarctic Pacific (Hutchins et al. 2001), in the equatorial
Pacific (Price et al. 1991, Cochlan 2001), and along the coast of California (Hutchins et al. 1998, 2001, Kirchman et al. 2000).

Siderophores are low molecular mass compounds with a high affinity for ferric ion that are secreted by microorganisms in response to low iron availability, facilitating iron acquisition and uptake (Reid et al. 1993, Lewis et al. 1995, Wilhelm et al. 1996, 1998). There have been only a few studies characterizing siderophore production in marine heterotrophic bacteria. Among these structurally identified siderophores are alterobactins, marinobactins and aquachelins, with iron-binding functional groups consisting of catechol and $\beta$-hydroxy-aspartate moieties (Reid et al. 1993, Butler 1998), aerobactin produced by a marine Vibrio species and containing 2 iron-binding hydroxamate moieties (Haygood et al. 1993), and desferrioxamine G, 
a trihydroxamate siderophore from a zooplanktonassociated Vibrio species (Martinez et al. 2001). Another study supported the importance of siderophores in Fe transport by heterotrophic marine bacteria, and suggested that bacteria may rely on siderophores to acquire Fe in situ (Granger \& Price 1999). Marine prokaryotes can also utilize Fe bound to exogenous siderophores, which has important implications for Fe acquisition and competition within the plankton community (Granger \& Price 1999, Hutchins et al. 1999, Guan et al. 2001).

The molecular structures of the dissolved organic ligands that bind virtually all of the dissolved Fe in the world's oceans are currently unknown. A variety of organic ligands are likely to be found in the open ocean environment, as suggested by studies of structurally characterized siderophores produced by a few cultured marine prokaryotes (Haygood et al. 1993, Wilhelm \& Trick 1994, Wilhelm et al. 1996, 1998, Butler 1998) and knowledge of the types of strong Fe chelators present in phytoplankton cells, such as porphyrins, that could be released by grazing or viral lysis (Hutchins et al. 1999, Witter et al. 2000). Porphyrins are components of chlorophylls and heme proteins (Geider \& LaRoche 1994) and are characterized by 4 pyrrole rings linked together by a methane bridge. Both siderophores and porphyrins have very high conditional stability constants for iron binding which are nearly identical to those of the natural ligands in seawater (Rue \& Bruland 1995, Witter et al. 2000).

The goal of this study was to determine the role that organic ligand structure plays in the acquisition of iron by heterotrophic bacteria, and thus provide one of the missing links to the cycling of Fe in the oceanic environment. To do this, we used model ligands chelated with ${ }^{55} \mathrm{Fe}$, such as those used by Hutchins et al. (1999). We hoped to determine whether heterotrophic bacteria show a preference for Fe bound to catecholate or hydroxamate siderophores, porphyrins or phytic acid, and whether differences exist in Fe utilization between 2 common marine bacterial subclasses, the alpha and gamma proteobacteria (Fuhrman et al. 1989, 1993, Delong et al. 1993, Cottrell \& Kirchman 2000). For both subclasses of proteobacteria, we predicted preferential utilization of Fe bound to siderophore-type model ligands and very little utilization of porphyrin-bound $\mathrm{Fe}$, as reported by Hutchins et al. (1999) for natural prokaryotic communities and cultured cyanobacteria.

We also compared the bioavailability of Fe bound to these ligands to bacterioplankton communities from 2 oceanographic regimes. The California upwelling regime is a high-nutrient coastal area where the phytoplankton community is dominated by large chainforming diatoms such as Chaetoceros spp., and the smaller size-classes consist mostly of nanophytoplank- ton and heterotrophic bacteria; cyanobacteria are virtually absent here. Large parts of this region are now known to be Fe-limited coastal HNLC environments (Hutchins \& Bruland 1998, Hutchins et al. 1998, Bruland et al. 2001). We also examined uptake of Fe from our model complexes by the natural bacterioplankton community in the oligotrophic Sargasso Sea, where communities consist mostly of picoplanktonic cyanobacteria (such as Synechococcus and Prochlorococcus) and bacteria (Hutchins et al. 1999).

\section{MATERIALS AND METHODS}

Model ligands. Model strong Fe chelators chosen for the laboratory and field Fe-uptake experiments included siderophores, porphyrins and phytic acid. Ligand structures are presented in Fig. 1, and logs of conditional stability constants for $\mathrm{Fe}$ binding with respect to free $\mathrm{Fe}^{3+}$ are presented in Table 1. Published conditional stability constants are not available for the dihydroxamate siderophore rhodoturulic acid or the porphyrin chlorin $\mathrm{e}_{6}$, but are likely similar to those of the other structurally similar ligands. Four different porphyrins were used: chlorin $\mathrm{e}_{6}$ (field experiments only), phaeophytin $a$, phaeophorbide $a$, and protoporphyrin IX (Fig. 1). Protoporphyrin IX is an intermediate in the formation of heme that could be released into the water column by grazing (Hutchins \& Bruland 1994), viral lysis (Gobler et al. 1997), or autolysis (Berges \& Falkowski 1998). Chlorin $\mathrm{e}_{6}$, phaeophorbide $a$, and phaeophytin $a$ are derivatives of chl a from which the Mg has been removed, as may happen when passing through the acidic stomach of grazers (Head \& Harris 1994), making them strong Fe chelators (Witter et al. 2000).

Table 1. Effect of model ligand treatments used in the experiments on the calculated chemical speciation of Fe in the uptake bottles. Shown are the logs of the ligand conditionalstability constants for $\mathrm{Fe}$ binding with respect to free ionic $\mathrm{Fe}^{3+}\left(\mathrm{K}_{\mathrm{LFe}}{ }^{3+}\right)$, and the resulting free ionic $\mathrm{Fe}^{3+}$ concentrations in the uptake bottles containing $5 \mathrm{nM}$ bound ${ }^{55} \mathrm{Fe}(\mathrm{FeL})$ and 20 $\mathrm{nM}$ free ligand (L). Stability constants were determined by Witter et al. (2000) using competitive ligand equilibration methods with $1 \mathrm{~N} 2 \mathrm{~N}$, except for enterobactin which was determined using the kinetic method of Wu \& Luther (1994)

\begin{tabular}{|lcc|}
\hline Ligand treatment & Log $\mathrm{K}_{\mathrm{LFe}^{3+}}$ & $\begin{array}{c}\text { Free ionic Fe con- } \\
\text { centration }\left(\mathrm{Fe}^{3+} ; \mathrm{M}\right)\end{array}$ \\
\hline Protoporphyrin IX & 22.4 & $1.00 \times 10^{-23}$ \\
Phaeophytin & 22.2 & $1.58 \times 10^{-23}$ \\
Phytic acid & 22.3 & $1.25 \times 10^{-23}$ \\
Enterobactin & 20.8 & $3.96 \times 10^{-22}$ \\
Desferrioxamine B & 21.6 & $6.28 \times 10^{-23}$ \\
\hline
\end{tabular}



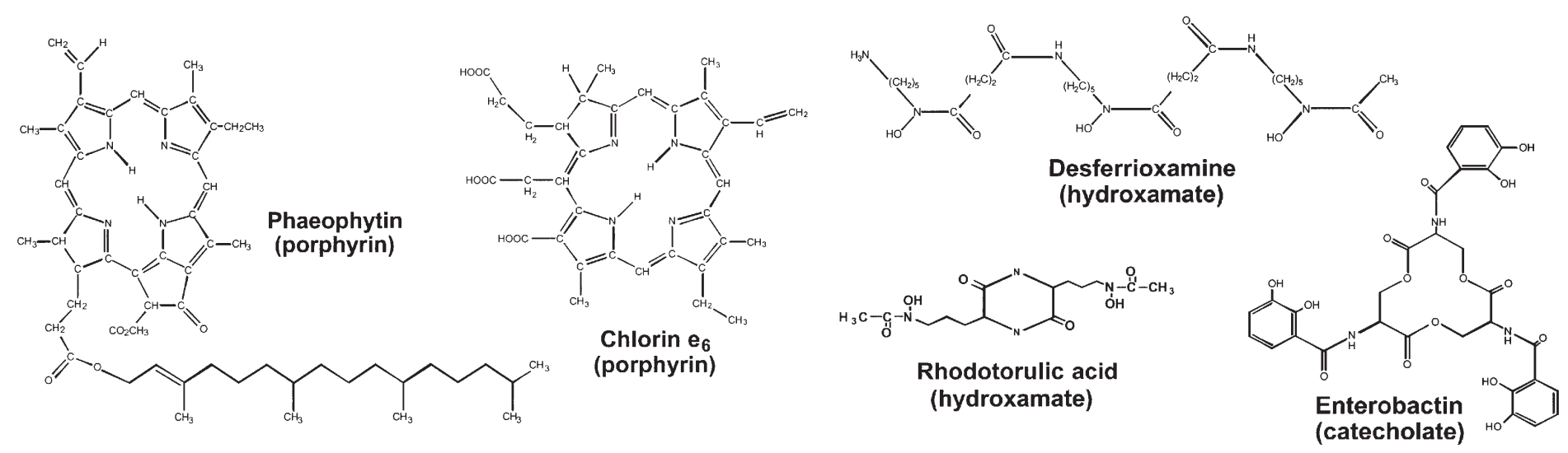

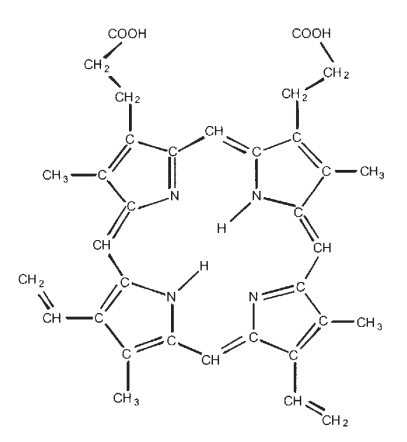

Protoporphyrin IX (porphyrin)

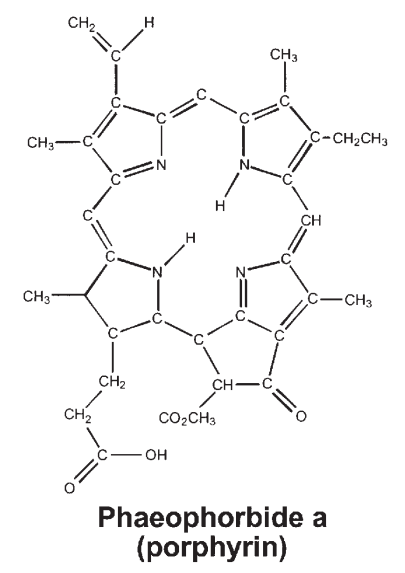

(porphyrin)

Fig. 1. Structures of the model ligands used in the laboratory and shipboard Fe uptake experiments, including porphyrin structures, phytic acid and siderophore structures

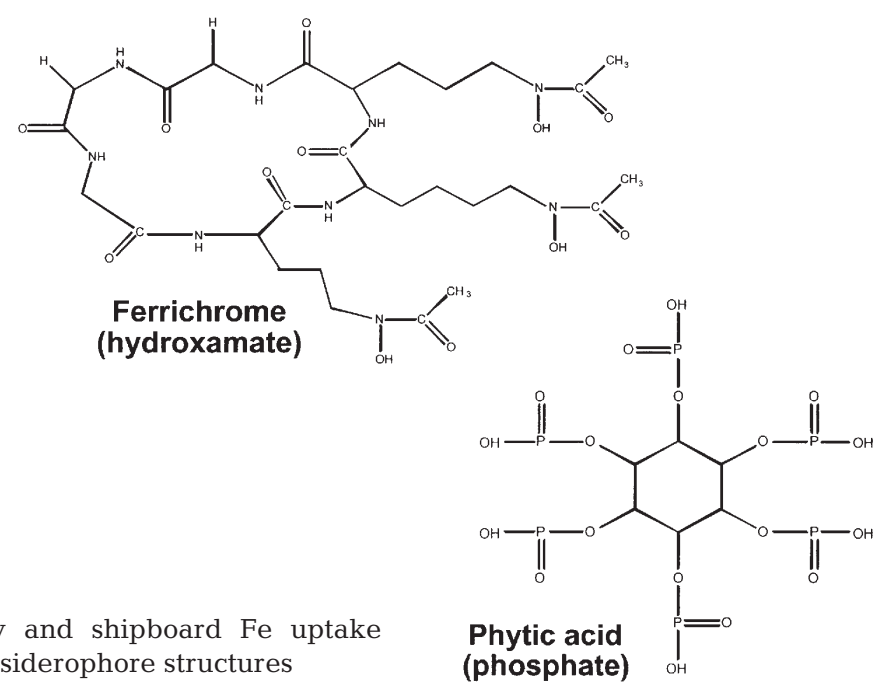

The siderophores used were enterobactin (lab experiments only), ferrichrome, desferrioxamine $B$, and rhodotorulic acid (Fig. 1). Ferrichrome and desferrioxamine $\mathrm{B}$ both contain tri-hydroxamate moieties, rhodotorulic acid has a di-hydroxamate functional group, and enterobactin is a catecholate siderophore. Desferrioxamine B differs from the marine bacterial siderophore desferrioxamine G only by the substitution of a terminal methyl group by a propionic acid group (Martinez et al. 2001), while rhodotorulic acid may be considered a general model for dihydroxamate marine siderophores like aerobactin (Haygood et al. 1993). Phytic acid, a strong Fe chelator with a hexa-phosphate inositol ring structure (Witter et al. 2000), was also used. It is not a siderophore or porphyrin, but is produced in abundance by terrestrial seeds, pollens, and spores. Suzumura \& Kamatani (1995) demonstrated that phytic acid can be abundant in coastal waters.

The ligand stocks were prepared and deferrated if needed as described in Witter et al. (2000). Concentrated ${ }^{55} \mathrm{Fe} /$ ligand stocks were prepared in acid washed $60 \mathrm{ml}$ polycarbonate bottles and were equilibrated in the dark for $24 \mathrm{~h}$ before use. For both laboratory and shipboard uptake experiments, model ligand/
${ }^{55} \mathrm{Fe}$ complexes were added to a final concentration of $5 \mathrm{nM}{ }^{55} \mathrm{Fe}\left(5.0 \times 10^{11} \mathrm{~Bq} \mathrm{~mol}^{-1}\right)$ bound to $25 \mathrm{nM}$ of ligand. The ligand was in excess to ensure that all ${ }^{55} \mathrm{Fe}$ would be complexed by the ligands, as well as to chelate any minor Fe contamination. The calculated free ferric ion concentrations $\left(\mathrm{Fe}^{3+}\right)$ in our experimental treatments are presented in Table 1 . Because these were 13 to 14 orders of magnitude lower than the $5 \mathrm{nM}$ complexed ${ }^{55} \mathrm{Fe}$ added, virtually all of the observed uptake had to come from the complexed Fe. Uptake from the ligand complexes was compared to uptake in treatments in which $5 \mathrm{nM}$ inorganic ${ }^{55} \mathrm{Fe}\left({ }^{55} \mathrm{FeCl}_{3}\right.$ in $0.01 \mathrm{M} \mathrm{HCl}$ ) was added directly to the incubation bottles without any chelating ligands.

Laboratory culture iron uptake experiments. Vibrio natriegens, a heterotrophic gamma proteobacterium, and IRI-16, a heterotrophic alpha proteobacterium, were the isolates chosen for the culture bioavailability experiments. These 2 subclasses are common in many marine environments (Giovanonni et al. 1990, Cottrell \& Kirchman 2000). These strains were selected for their ability to be cultured in minimal medium, and because they reach exponential growth phase in approximately 12 to $15 \mathrm{~h}$. 
The minimal media for the lab experiments were prepared using $0.2 \mu \mathrm{m}$ filtered seawater collected from the low-Fe, oligotrophic waters of the Sargasso Sea, using trace-metal clean techniques (Hutchins et al. 1998). This water was brought back to the lab and stored in the dark under refrigeration until needed for experiments. It was passed through a UV oxidation system (Kontes, Ace Glass, 1200 W, seawater residence time $\sim 5 \mathrm{~h}$ ) to remove any natural organic ligands (Donat \& Bruland 1988) before use in the experiments. Minimal medium was prepared by adding $35 \mathrm{mM}$ glucose, $6 \mathrm{mM}$ ammonium, and $0.1 \mathrm{mM}$ phosphate to the UV oxidized seawater (final pH 7.8). The medium was then microwave sterilized for $24 \mathrm{~min}$. and allowed to cool overnight (Keller et al. 1988).

To remove any trace-Fe contamination, Fe-deplete medium for growing Fe-limited cultures was passed through a chelex 100 column (Price et al. 1989). Fereplete medium was prepared by adding $2.5 \times 10^{-8} \mathrm{M}$ Fe/EDTA. Fe-free solutions of trace metals and $f / 2$ vitamins were added to the chelated and un-chelated media (Price et al. 1989).

Bacteria were transferred from a Luria-medium agar plate into $50 \mathrm{ml}$ Fe-replete minimal medium, grown to exponential growth phase (12 to $15 \mathrm{~h})$, and then harvested by centrifugation. The resulting pellet was resuspended in Fe-deplete medium to wash extracellular Fe from the cells, and once again harvested by centrifugation. The bacteria were then resuspended in $10 \mathrm{ml} \mathrm{Fe}$-deplete medium, and $250 \mu \mathrm{l}$ of the resuspended concentrated cells were transferred in triplicate into $25 \mathrm{ml}$ of Fe-replete medium and Fe-deplete medium. The cells were transferred to fresh medium every 12 to $15 \mathrm{~h}$ until the bacteria in the Fe-deplete medium were grown into Fe limitation. Bacterial growth was monitored by measuring absorbance at $600 \mathrm{~nm}$ during the experiments. Samples for bacterial cell counts were preserved in $2 \%$ formaldehyde, stained with acridine orange, and counted using epifluorescence microscopy (Hobbie et al. 1977).

Fe uptake experiments were prepared by adding $1 \mathrm{ml}$ of the equilibrated ligand $/{ }^{55} \mathrm{Fe}$ stock solutions to $20 \mathrm{ml}$ of Fe-deplete medium in acid washed polycarbonate incubation bottles. Once the bacteria in Fedeplete medium were Fe-limited and both treatments were in exponential growth phase, cells were concentrated by centrifugation and $250 \mu$ l of the cells were added to each uptake bottle. All treatments were run in triplicate. The cells were allowed to take up Fe for $2 \mathrm{~h}$, and were then filtered onto a $0.2 \mu \mathrm{m}$ filter, rinsed with $\mathrm{Ti}$ (III) reagent to remove any extracellular iron (Hudson \& Morel 1989), and radioassayed. Iron uptake $\left(\mathrm{mol} \mathrm{ml} \mathrm{m}^{-1} \mathrm{~h}^{-1}\right)$ for each ligand was determined from the resulting counts of ${ }^{55} \mathrm{Fe}$ disintegrations $\mathrm{min}^{-1}$ and the specific activity of the isotope, as described in Schmidt
\& Hutchins (1999), and was then normalized to bacterial cell concentrations ( $\mathrm{mol}{ }^{55} \mathrm{Fe} \mathrm{cell}^{-1} \mathrm{~h}^{-1}$ ).

Shipboard natural community iron uptake experiments. Unfiltered near-surface (5 to $10 \mathrm{~m}$ ) seawater samples containing natural plankton communities were obtained using a trace-metal clean Teflon pump system (Hutchins et al. 1998) aboard the RV 'Point Sur' in June 1999 in the California upwelling regime, and the RV 'Cape Henlopen' in June 2000 in the Sargasso Sea. Collection sites for our experiments are shown in Fig. 2A (California) and Fig. 2B (Sargasso Sea). The water was collected in an acid washed 501 carboy under trace-metal clean conditions, and then transferred into $2.7 \mathrm{l}$ acid-washed polycarbonate bottles. Model ligand $/{ }^{55} \mathrm{Fe}$ complexes were added and the bottles were placed in flow-through deck-board incubators to simulate ambient temperature and light conditions at the $40 \%$ light level. The bottles were incubated for approximately $48 \mathrm{~h}$ to allow sufficient uptake of ${ }^{55} \mathrm{Fe}$ from the model ligand complexes for good counting statistics $(<5 \%$ counting error). Duplicate treatments of each ligand were used in the California upwelling and triplicate treatments of each ligand were used in the Sargasso Sea.

As in the laboratory experiments, treatments were included in which $5 \mathrm{nM}$ inorganic ${ }^{55} \mathrm{Fe}\left({ }^{55} \mathrm{FeCl}_{3}\right.$ in $0.01 \mathrm{M} \mathrm{HCl}$ ) was added directly to the incubation bottles without any added model ligands. Due to rapid complexation kinetics (Witter et al. 2000), the added Fe quickly equilibrates with any natural excess ligands in the seawater sample, and so cannot be assumed to remain in inorganic form. Fe uptake from the model ligand complexes in the other treatments was normalized to the 'inorganic' treatments to allow comparisons of relative uptake between different ligands and different stations.

After the $48 \mathrm{~h}$ incubation period, the seawater was pre-filtered through a $1.0 \mu \mathrm{m}$ polycarbonate filter (Poretics) to remove large phytoplankton and grazers. The remaining bacterioplankton were then collected on $0.2 \mu \mathrm{m}$ filters and washed with $\mathrm{Ti}$ (III) reagent to remove any extracellular iron (Hudson \& Morel 1989). ${ }^{55} \mathrm{Fe}$ radioassays of the filters and bacterial cell counts of preserved samples were carried out as described above for the laboratory experiments.

All field uptake data are presented as mol Fe cell-1 taken up over the whole $2 \mathrm{~d}$ incubation, rather than as an uptake rate. Because these are not short-term uptake measurements with relatively constant biomass (as in the laboratory experiments), presentation as an uptake rate is not appropriate. Results are presented as the averages of triplicate or duplicate samples, and the error bars represent standard deviations (Sargasso) or ranges (California) of the replicates. As noted above, to allow for a comparison between stations and environ- 
ments, the uptake values of the organically bound Fe were normalized to uptake of the inorganic Fe. A normalized value $>1$ suggests that the bacterioplankton community utilized the organically bound $\mathrm{Fe}$ more efficiently than the inorganic $\mathrm{Fe}$, and a value $<1$ suggests they were less available than inorganic Fe. Error bars were calculated by propagation of error. Sizefractionated fluorometric chl a $(0.2,1.0$ and $8.0 \mu \mathrm{m}$, California) or total chl a (>0.2 $\mu \mathrm{m}$, Sargasso) and nutrient measurements $\left(\mathrm{NO}_{3}{ }^{-}, \mathrm{PO}_{4}{ }^{3-}\right.$ and $\left.\mathrm{SiOH}_{4}\right)$ were made with standard methods (Parsons et al. 1984).

\section{RESULTS}

\section{Iron uptake by a gamma proteobacterium}

In every case, Fe-limited cultures of the gamma proteobacterium Vibrio natriegens had significantly higher cell-normalized Fe uptake rates (1-way ANOVA, $\mathrm{p}<0.05$ ) than the Fe-replete cultures (Fig. 3). Fe uptake rates were highest in the treatment with added

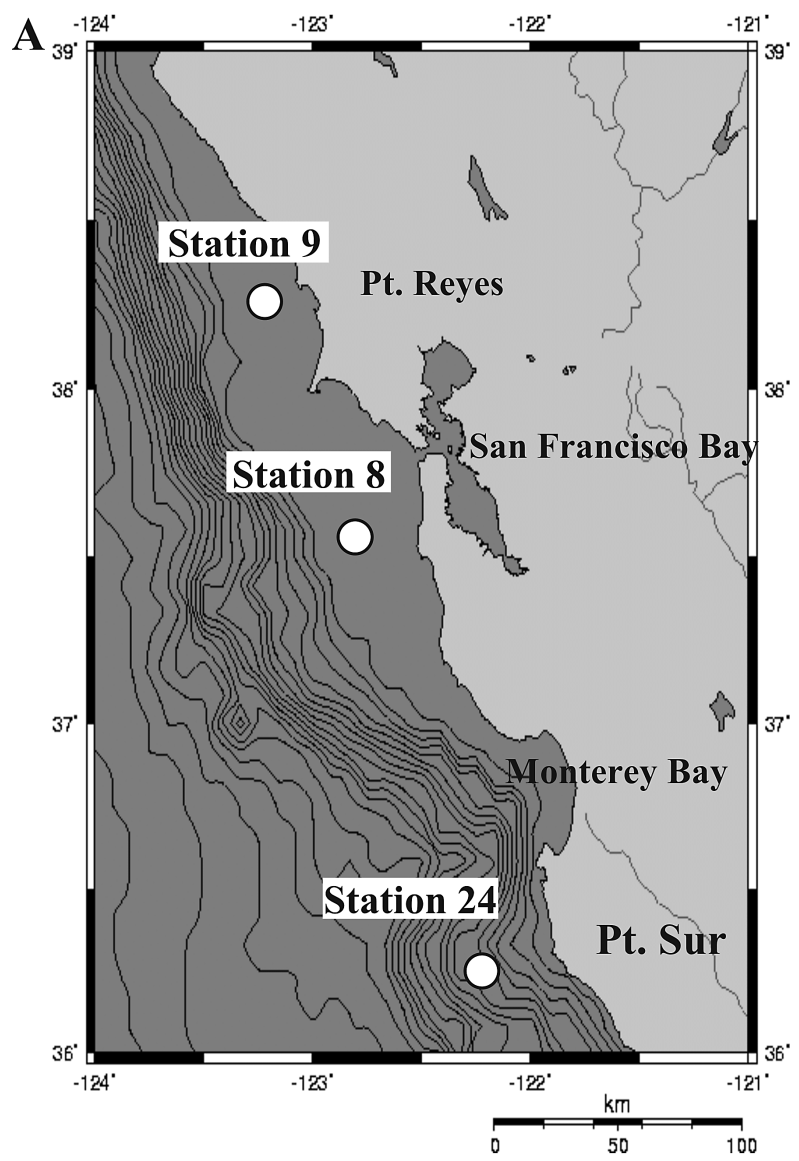

inorganic Fe. In general, Fe-utilization rates were slightly to markedly higher in the siderophore treatments when compared to the porphyrin treatments. Of the various ligand complexes, the highest uptake rates were of $\mathrm{Fe}$ bound to the dihydroxamate siderophore rhodotorulic acid: $23 \%$ less than from inorganic $\mathrm{Fe}$ in the Fe-replete treatment, and $37 \%$ less than from inorganic $\mathrm{Fe}$ in the Fe-deplete treatment (Fig. 3A). The Fe-deplete bacteria had a somewhat lesser ability to utilize Fe bound to the trihydroxamate siderophore desferrioxamine B, with uptake rates that were $76 \%$ less than the inorganic Fe treatment. The Fe-replete bacteria used Fe bound to the siderophore desferrioxamine $\mathrm{B}$ and the porphyrin phaeophytin with about equal efficiency $\left(\sim 16 \times 10^{-22}\right.$ mol Fe cell ${ }^{-1} \mathrm{~h}^{-1}$ ). Both the Fe-deplete and Fe-replete $V$. natriegens cells used little of the Fe bound to phaeophorbide $(97 \%$ less than the inorganic treatment).

The second experiment with Vibrio natriegens used a different set of model ligand $/{ }^{55} \mathrm{Fe}$ complexes (Fig. 3B). The average cell-normalized uptake rate in the inor-

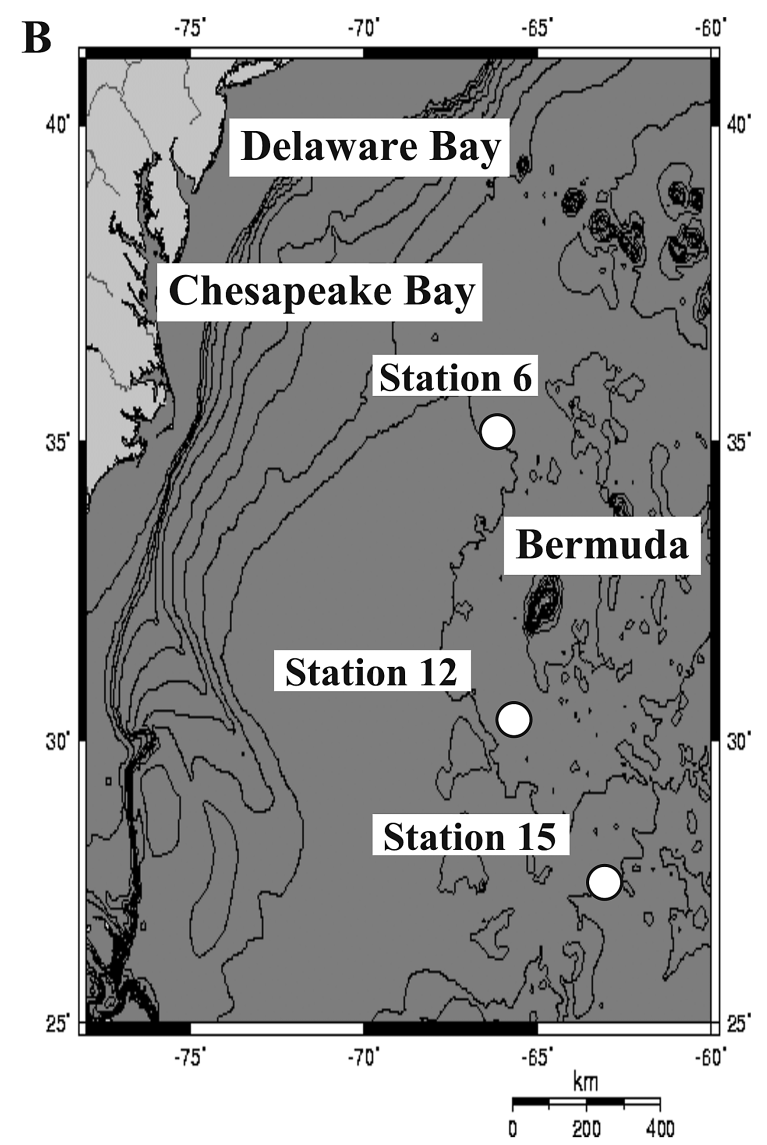

Fig. 2. Sampling sites where water was collected for the shipboard iron uptake experiments. (A) California upwelling (Stns 8, 9 and 24), (B) Sargasso Sea (Stns 6, 12 and 15) 
ganic treatment was almost 3 times greater than in the first experiment. As in the first experiment, uptake rates were also highest in the inorganic Fe treatment. Fe bound to enterobactin (a catecholate siderophore) was the most available of all the ligand treatments, at
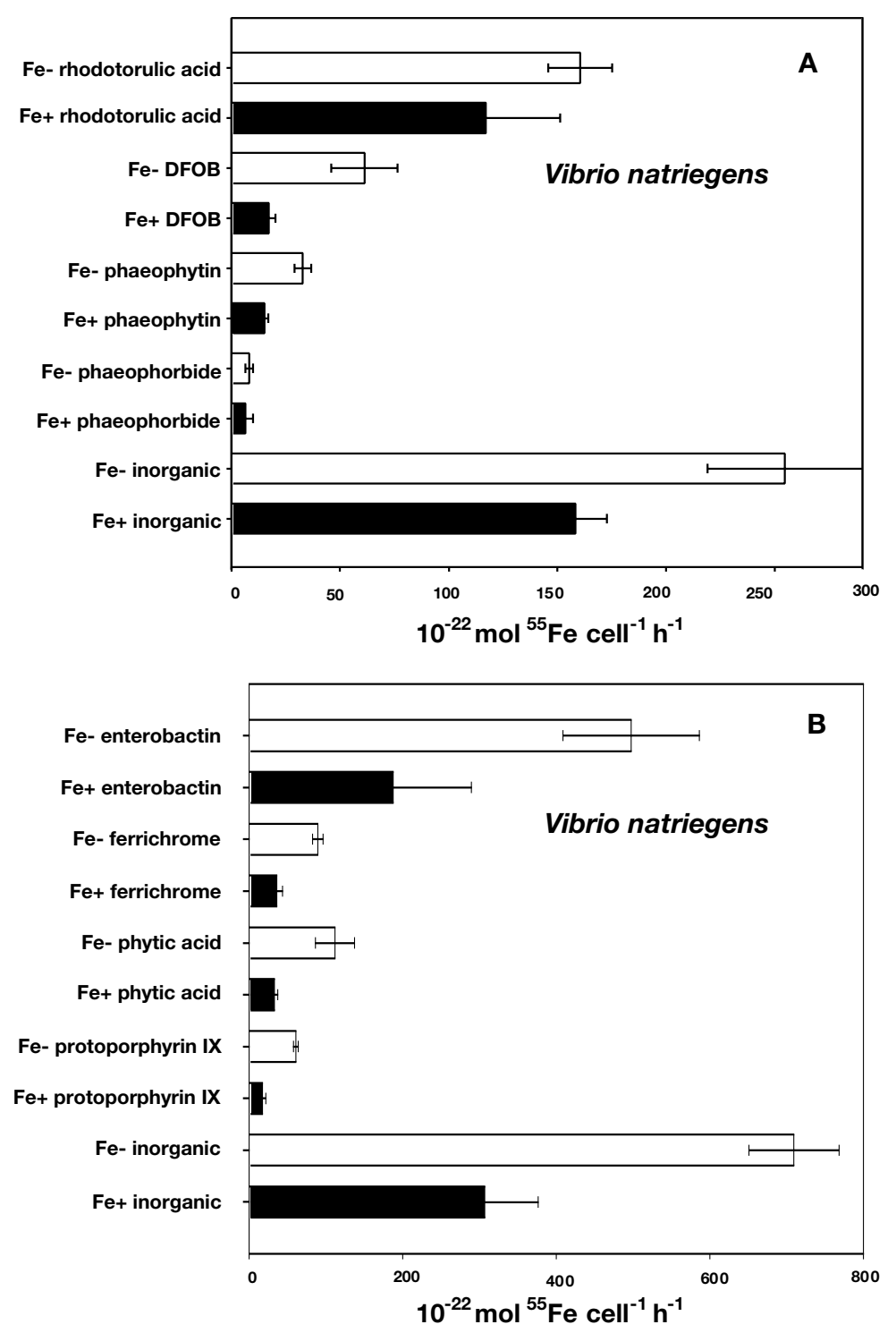

Fig. 3. Vibrio natriegens. Fe uptake by the gamma proteobacterium in 2 experiments using different sets of model Fe/ligand complexes. (A) The first experiment using ${ }^{55} \mathrm{Fe}$ complexed to the dihydroxamate siderophore rhodotorulic acid, the trihydroxamate siderophore desferrioxamine B (DFOB), and the porphyrins phaeophytin and phaeophorbide. (B) The second experiment using the catecholate siderophore enterobactin, the trihydroxamate siderophore ferrichrome, the porphyrin protoporphyrin IX, and the phosphate chelator phytic acid. In both experiments, Fe uptake from the ligand complexes was compared to the uptake of Fe added in inorganic form. Fe uptake is expressed as mol Fe cell ${ }^{-1}$ $\mathrm{h}^{-1}$. White bars represent Fe uptake in Fe-deplete cells, and black bars represent Fe uptake in Fe-replete cells. Values and error bars represent the means $\pm \mathrm{SD}$ of 3 replicate cultures
$497 \times 10^{-22}$ mol Fe cell ${ }^{-1} \mathrm{~h}^{-1}$ in the Fe-deplete treatment (30\% less than the Fe-deplete inorganic treatment). Uptake rates in the Fe-replete enterobactin treatments were $187 \times 10^{-22}$ mol Fe cell ${ }^{-1} \mathrm{~h}^{-1}, 39 \%$ less than the Fe-replete inorganic treatment.

The other types of ligand complexes were relatively less available to Vibrio natriegens (Fig. 3B). The Fe-deplete phytic acid treatment had the next highest uptake rate $\left(111 \times 10^{-22} \mathrm{~mol}\right.$ Fe cell ${ }^{-1} \mathrm{~h}^{-1}$, $84 \%$ less than the inorganic treatment) followed by the Fe-deplete ferrichrome treatment $\left(89 \times 10^{-22}\right.$ mol Fe cell ${ }^{-1} \mathrm{~h}^{-1}, 87 \%$ less than the inorganic treatment). The Fe-limited bacteria had the least success utilizing Fe bound to protoporphyrin IX $(91 \%$ less than the inorganic treatment). The Fe-replete bacteria had similar, very low uptake rates in the protoporphyrin IX, phytic acid, and ferrichrome treatments (approx. $30 \times 10^{-22}$ mol Fe cell ${ }^{-1} \mathrm{~h}^{-1}$, $~ 90 \%$ less than the inorganic treatment).

\section{Iron uptake by an alpha proteobacterium}

We used the same model ligand $/{ }^{55} \mathrm{Fe}$ complexes with an alpha proteobacterium (IRI-16, Fig. 4). Like the gamma proteobacterial isolate, uptake rates by IRI-16 were always higher in the Fe-deplete than in the Fe-replete cultures ( $p<$ 0.03), regardless of the chemical speciation of Fe. However, uptake by IRI-16 was minimal from all of the ligand complexes compared to the inorganic treatment. Fe uptake rates were $311 \times$ $10^{-22}$ mol Fe cell ${ }^{-1} \mathrm{~h}^{-1}$ in the Fe-deplete inorganic Fe treatment, greater than in all other Fedeplete ligand treatments by at least $90 \%$, and $46 \times 10^{-22} \mathrm{~mol} \mathrm{Fe} \mathrm{cell}{ }^{-1} \mathrm{~h}^{-1}$ in the Fe-replete inorganic treatment, exceeding $\mathrm{Fe}$ uptake in the other Fe-replete ligand treatments by at least $69 \%$ (Fig. 4A).

IRI-16 demonstrated very little preference for particular ligand structures and little ability to use Fe bound to any of our model ligands. Uptake by the Fe-limited bacteria did not differ significantly between ligand treatments ( $p>0.05$ ). Uptake by the Fe-limited cells in the phaeophorbide treatment $\left(18 \times 10^{-22} \mathrm{~mol} \mathrm{Fe}\right.$ cell $^{-1} \mathrm{~h}^{-1}$ ) was $94 \%$ less than in the Fe-limited inorganic treatment. Fe-limited cells in the phaeophytin $\left(21 \times 10^{-22} \mathrm{~mol} \mathrm{Fe} \mathrm{cell}{ }^{-1} \mathrm{~h}^{-1}\right)$ and rhodotorulic acid $\left(22 \times 10^{-22} \mathrm{~mol} \mathrm{Fe} \mathrm{cell}{ }^{-1} \mathrm{~h}^{-1}\right)$ treatments both had uptake rates $93 \%$ less than in the Fe-limited inorganic treatment, while uptake of desferrioxamine B $\left(29 \times 10^{-22} \mathrm{~mol} \mathrm{Fe}\right.$ cell $^{-1} \mathrm{~h}^{-1}$ ) was $91 \%$ less. The Fe-replete bacteria 
took up very little of any of the organically bound Fe. Uptake rates in the phaeophorbide $\left(6.6 \times 10^{-22} \mathrm{~mol} \mathrm{Fe}\right.$ cell $\left.^{-1} \mathrm{~h}^{-1}\right)$ and rhodotorulic acid $\left(6.5 \times 10^{-22} \mathrm{~mol} \mathrm{Fe}\right.$ cell $^{-1} \mathrm{~h}^{-1}$ ) treatments were both $86 \%$ less than in the inorganic treatment. Uptake rates in the phaeophytin $\left(4.4 \times 10^{-22} \mathrm{~mol} \mathrm{Fe} \mathrm{cell}{ }^{-1} \mathrm{~h}^{-1}\right)$ and desferrioxamine B $\left(14.5 \times 10^{-22} \mathrm{~mol} \mathrm{Fe} \mathrm{cell}{ }^{-1} \mathrm{~h}^{-1}\right)$ treatments were 81 and $69 \%$ less than the inorganic treatment.

The results of the other IRI-16 experiment (Fig. 4B) were similar. Fe utilization was 1 to 2 orders of magnitude greater in the inorganic Fe treatments than in any of the ligand treatments. Inorganic Fe uptake rates were $471 \times 10^{-22} \mathrm{~mol} \mathrm{cell}^{-1} \mathrm{~h}^{-1}$ (Fe-deplete) and $94 \times 10^{-22} \mathrm{~mol}$ cell $^{-1} \mathrm{~h}^{-1}$ (Fe-replete). In contrast, Fe-replete protoporphyrin IX $\left(2.1 \times 10^{-22} \mathrm{~mol} \mathrm{cell}^{-1} \mathrm{~h}^{-1}\right)$ and ferrichrome $\left(2.8 \times 10^{-22} \mathrm{~mol} \mathrm{cell}^{-1} \mathrm{~h}^{-1}\right) \mathrm{up}$ take rates were about $98 \%$ less than the Fereplete inorganic treatment, and Fe-replete phytic acid, ferrichrome, and enterobactin uptake rates were about $90 \%$ lower. The Fedeplete bacteria in the enterobactin, ferrichrome, and phytic acid treatments also had uptake rates $\sim 90 \%$ less than in the Fe-deplete inorganic treatment. Fe uptake in the Fedeplete protoporphyrin IX treatment was 4fold lower than in the other Fe-deplete treatments $\left(12 \times 10^{-22}\right.$ mol Fe cell $\left.{ }^{-1} \mathrm{~h}^{-1}\right)$.

\section{Iron uptake in the California upwelling}

The areas studied in the California upwelling regime ranged from Fe-replete at Stn 8 (1.62 nM) to Fe-stressed at Stn 24 (0.14 nM) as discussed in Hutchins et al. (1998) and Kirchman et al. (2000). Table 2 presents the biological and biogeochemical characteristics of the water collected at each station. Stn 8 had high major nutrient concentrations and the highest bacterial counts and ambient dissolved Fe concentrations of any station examined. Stn 9 had fewer bacterial cells $\mathrm{ml}^{-1}$ than Stn $8\left(6.36 \times 10^{5}\right.$ vs $\left.8.83 \times 10^{5}\right)$ and a slightly lower ambient dissolved $\mathrm{Fe}$ concentration. The lowest ambient dissolved Fe, bacterial cell counts, and nutrient concentrations of the 3 California upwelling stations were at Stn 24.

Uptake of Fe added in inorganic form by the bacterial size-class $(0.2$ to $1.0 \mu \mathrm{m})$ in the California region was $\sim 2 \times 10^{-18} \mathrm{~mol}{ }^{55} \mathrm{Fe}$ cell ${ }^{-1}$ over $2 \mathrm{~d}$ at Stns 8 and 24, but was about 3 -fold higher $\left(6.5 \times 10^{-18} \mathrm{~mol}{ }^{55} \mathrm{Fe}\right.$ cell $^{-1}$ ) at Stn 9 (Fig. 5). However, because of the relatively large variability in the dupli- cate inorganic Fe bottles at these stations, this difference is not significant at the $95 \%$ confidence level.

$\mathrm{Fe}$ bound to the siderophores ferrichrome and rhodotorulic acid was the most readily available to the 0.2 to $1.0 \mu \mathrm{m}$ size-class at Stns 9 and 24 (Fig. 5). The bacterial size-class could also use Fe bound to desferrioxamine B $\left(\sim 2.6 \times 10^{-18} \mathrm{~mol}^{55} \mathrm{Fe} \mathrm{cell}^{-1}\right)$ at Stn 24 , but uptake was $\sim 50 \%$ less than from the rhodotorulic acid complex. At Stn 8, Fe chelated to the porphyrin phaeophytin was readily utilized by the bacterial size-class $\left(\sim 3.8 \times 10^{-18} \mathrm{~mol}^{55} \mathrm{Fe} \mathrm{cell}{ }^{-1}\right)$, but the structurally similar porphyrin phaeophorbide was virtually unavailable. However, at Stn 24, Fe uptake from the phaeophorbide

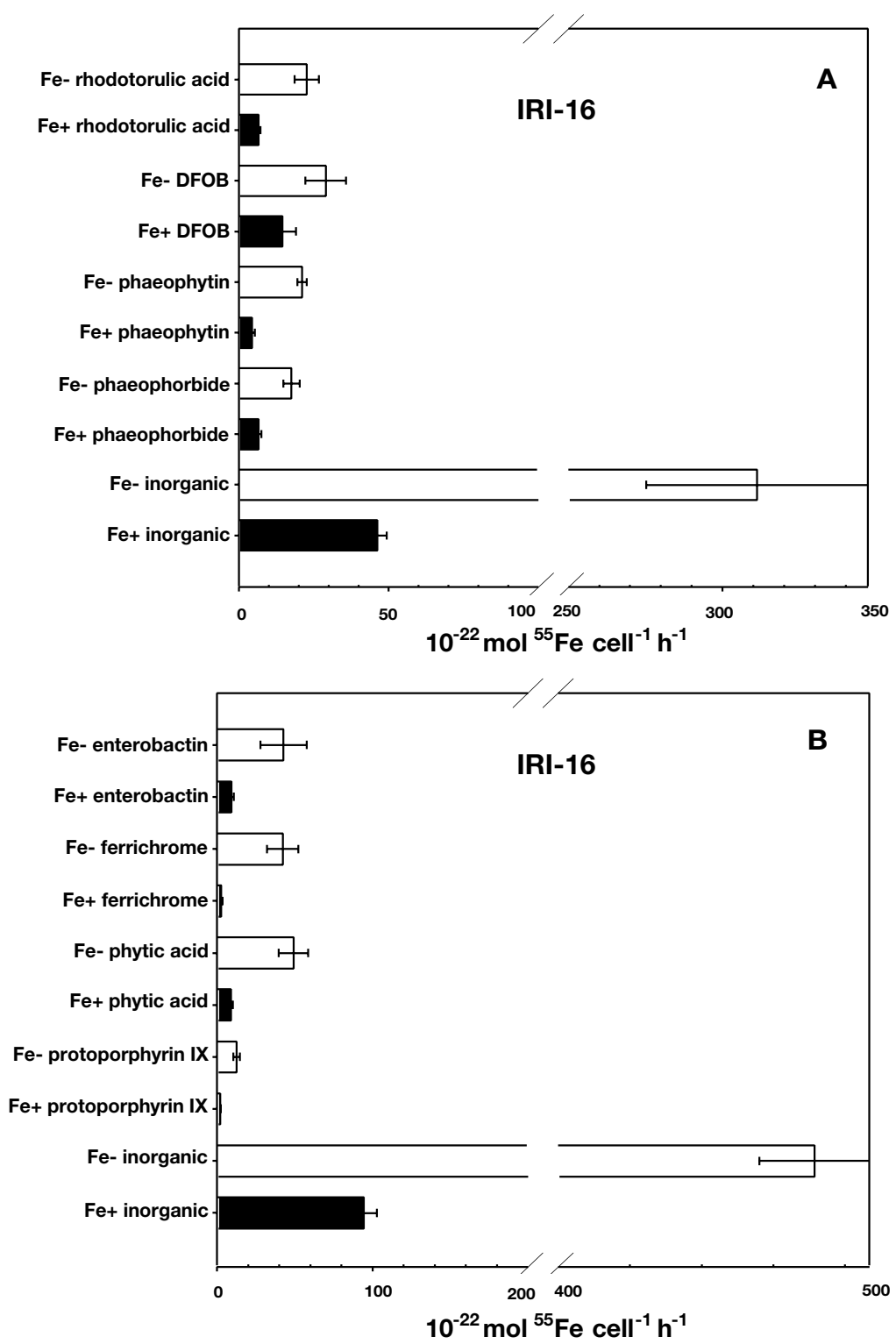

Fig. 4. Fe uptake by the alpha proteobacterium IRI-16 in 2 experiments using different sets of model Fe/ligand complexes (A and B). All other details as in Fig. 3 


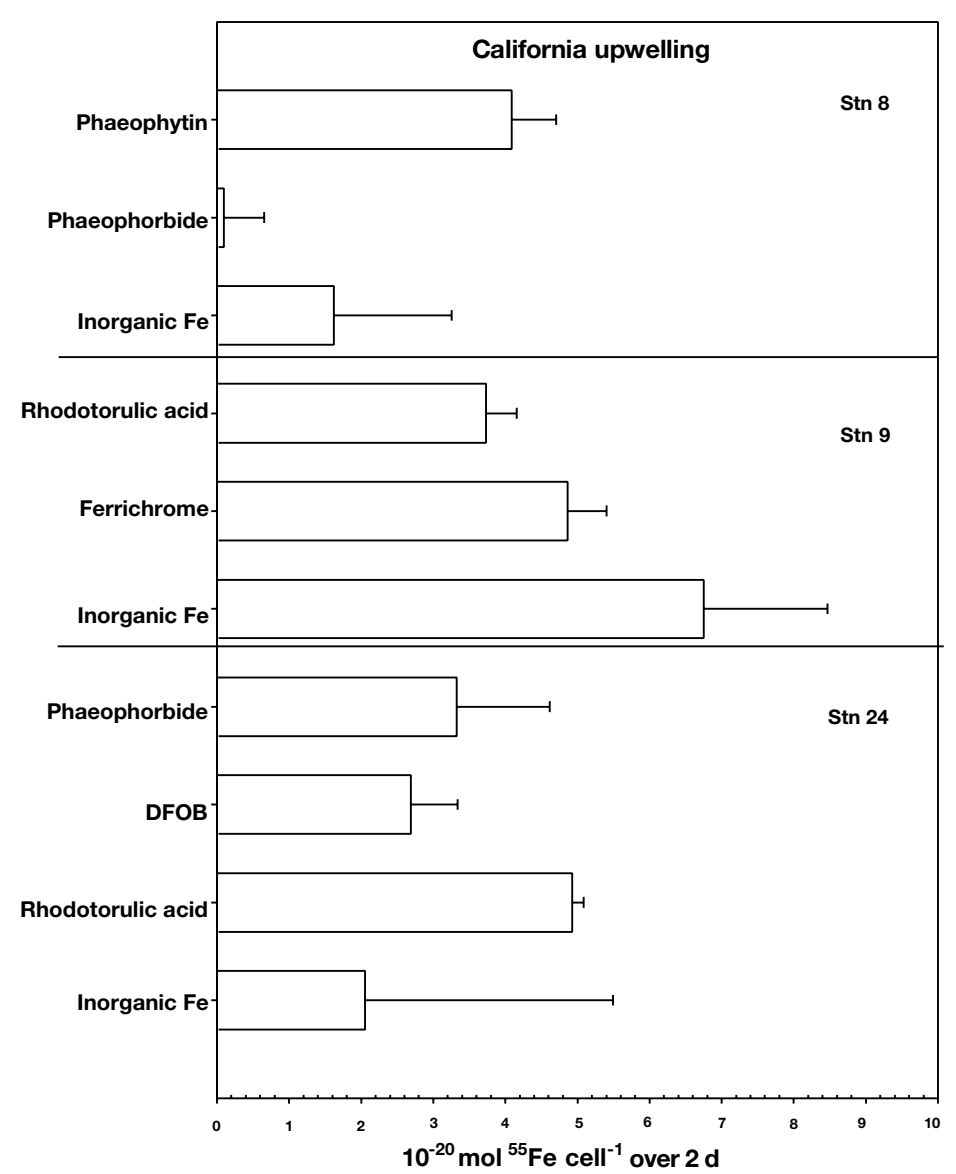

Fig. 5. Uptake of ligand-complexed Fe and Fe added in inorganic form expressed as mol Fe cell ${ }^{-1}$ over a $2 \mathrm{~d}$ period by the natural bacterioplankton community at 3 stations in the California upwelling region. Values and error bars represent the means + ranges of 2 duplicate bottles

complex $\left(\sim 3.3 \times 10^{-18} \mathrm{~mol}^{55} \mathrm{Fe} \mathrm{cell}^{-1}\right)$ was comparable to the 2 hydroxamate siderophores.

Fig. 6 presents the California uptake data normalized to the uptake of inorganic Fe. This data treatment suggests that Fe bound to phaeophytin at Stn 8 in the California upwelling was utilized about as efficiently (relative to inorganic $\mathrm{Fe}$ ) as $\mathrm{Fe}$ bound to rhodotorulic acid at Stn 24; both were much more available than Fe added in the inorganic form $(2.5 \times$ and $2.4 \times$ greater, respectively). Fe bound to rhodotorulic acid at Stn 9 was used less efficiently than inorganic Fe $(0.6 \times)$, but this same ligand was much more available than inorganic Fe at Stn 24 (2.4). At Stn 9, inorganic Fe was more efficiently used by the bacterioplankton community than either of the 2 hydroxamate siderophores (rhodotorulic acid $0.6 \times$, ferrichrome $0.7 \times$ ). The inorganic Fe-normalized uptake of phaeophorbide-bound $\mathrm{Fe}$ at Stn 8 (0.1) was negligible compared to Stn 24, where the Fe/phaeophorbide complex was more available than inorganic Fe (1.6).

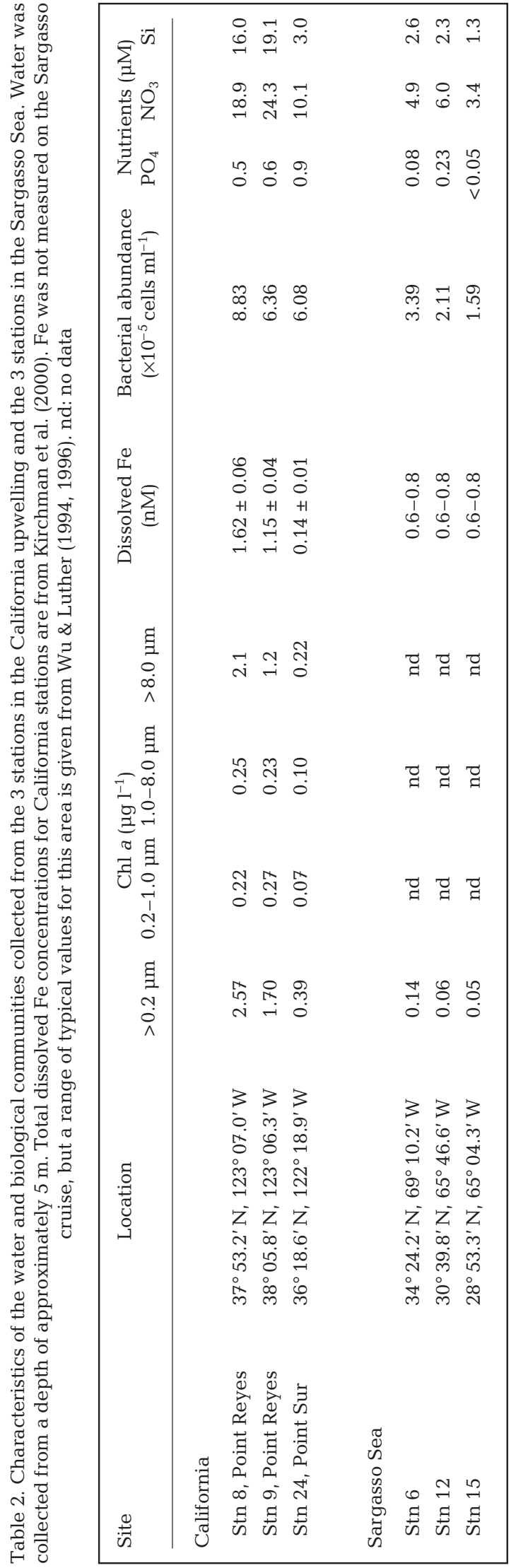




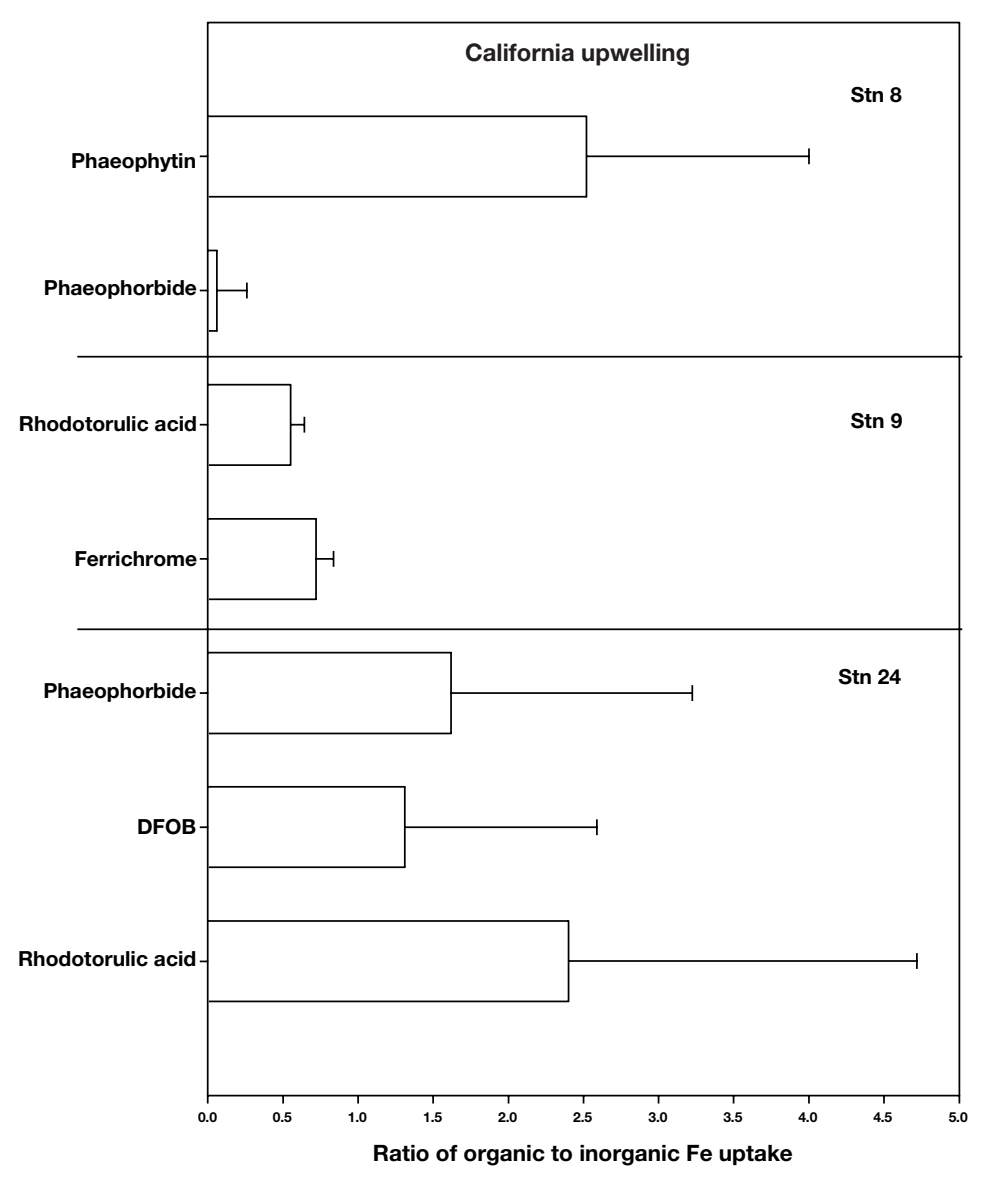

Fig. 6. Ligand-complexed Fe uptake normalized to inorganic Fe uptake in the California upwelling. Relative uptake is expressed as a decimal fraction of inorganic Fe uptake. Error bars were calculated by propagation of error

\section{Iron uptake in the Sargasso Sea}

The oligotrophic, cyanobacteria-dominated waters of the Sargasso Sea were much less biologically and biogeochemically variable than California waters (Table 2). Phosphate was at or near limits of detection $(<0.05 \mu \mathrm{M})$, but nitrate concentrations during our springtime cruise were relatively high for this area (3.4 to $6.0 \mu \mathrm{M})$, probably due to vertical mixing events immediately before and during the cruise. Although dissolved Fe was not measured during our cruise, previous work in this region has typically measured levels that range from 0.60 to $0.80 \mathrm{nM}$ (Wu \& Luther 1994, 1996). Total chl a levels were also low, ranging from 0.05 to $0.14 \mu \mathrm{g} \mathrm{l}^{-1}$ (Table 2). Bacterial cell counts were highest at Stn 6 where the total chl a value was the highest, but were lower at Stn 12 where the total chl a value was about half that of Stn 6 . Stn 12 had the highest nitrate levels of the 3 Sargasso Sea stations, and Stn 15 had the lowest values of all the parameters measured.
In the Sargasso Sea incubations at Stns 6 and 15, uptake of Fe originally added in inorganic form was much higher (up to 100-fold) than from any of the ligand complexes (Fig. 7). At Stn 12, however, Fe uptake in the inorganic treatments was approximately equal to uptake in the 2 porphyrin-complexed treatments (chlorin $\mathrm{e}_{6}$ and phaeophorbide $\sim 1.8 \times 10^{-20} \mathrm{~mol}{ }^{55} \mathrm{Fe} \mathrm{cell}^{-1}$, over a 2 d period). Porphyrin-bound Fe was more available to the bacterial size-class than siderophore-bound Fe at Stns 12 and 15, but there was no significant difference between the porphyrin and rhodotorulic acid treatments at Stn 6 ( $p>0.05)$. Fe bound to the trihydroxamate siderophores ferrichrome and desferrioxamine B was relatively unavailable to the community at Stn $12\left(<0.2 \times 10^{-20} \mathrm{~mol}{ }^{55} \mathrm{Fe}\right.$ cell $^{-1}$ over a $2 \mathrm{~d}$ period). The availability of phytic acid-complexed Fe was similar to rhodotorulic acid at Stn $15\left(\sim 0.7 \times 10^{-20} \mathrm{~mol}{ }^{55} \mathrm{Fe}\right.$ cell $^{-1}$ over a $2 \mathrm{~d}$ period), and not significantly different from the porphyrin and rhodotorulic acid complexes at Stn $6(\mathrm{p}>0.05)$.

Normalization of the same Sargasso Sea organic Fe uptake data (Fig. 8) suggests that very little of the organically bound Fe was utilized at any station in the Sargasso Sea relative to inorganic $F e$, except for Fe bound to chlorin $\mathrm{e}_{6}$ (1.1) and phaeophorbide (0.8) at Stn 12. All other average inorganic Fe-normalized values are $<0.4$, suggesting that Fe added in the inorganic form was much more efficiently utilized than the Fe complexed to the model ligands. Normalized uptake of Fe bound to protoporphyrin IX at Stn 6 (0.40) was $\sim 5.5 \times$ greater than Fe bound to same ligand at Stn 15 (0.07). Stn 6 also demonstrated considerably higher normalized utilization of the rhodotorulic acid (0.42) and phytic acid complexes (0.23) than at Stn 15 (both 0.02).

\section{DISCUSSION}

\section{Uptake of inorganic versus organically bound Fe}

In many of our laboratory and field experiments, iron originally added in inorganic form was the most available to marine bacteria. Both the cultured alpha and gamma proteobacteria had the highest Fe uptake rates in the treatments where Fe was added in inorganic form. In particular, the alpha proteobacterium IRI-16 demonstrated very little ability to utilize organically bound $\mathrm{Fe}$, but uptake was also highest in the inorganic treatments for the gamma proteobacterium Vibrio natriegens. 


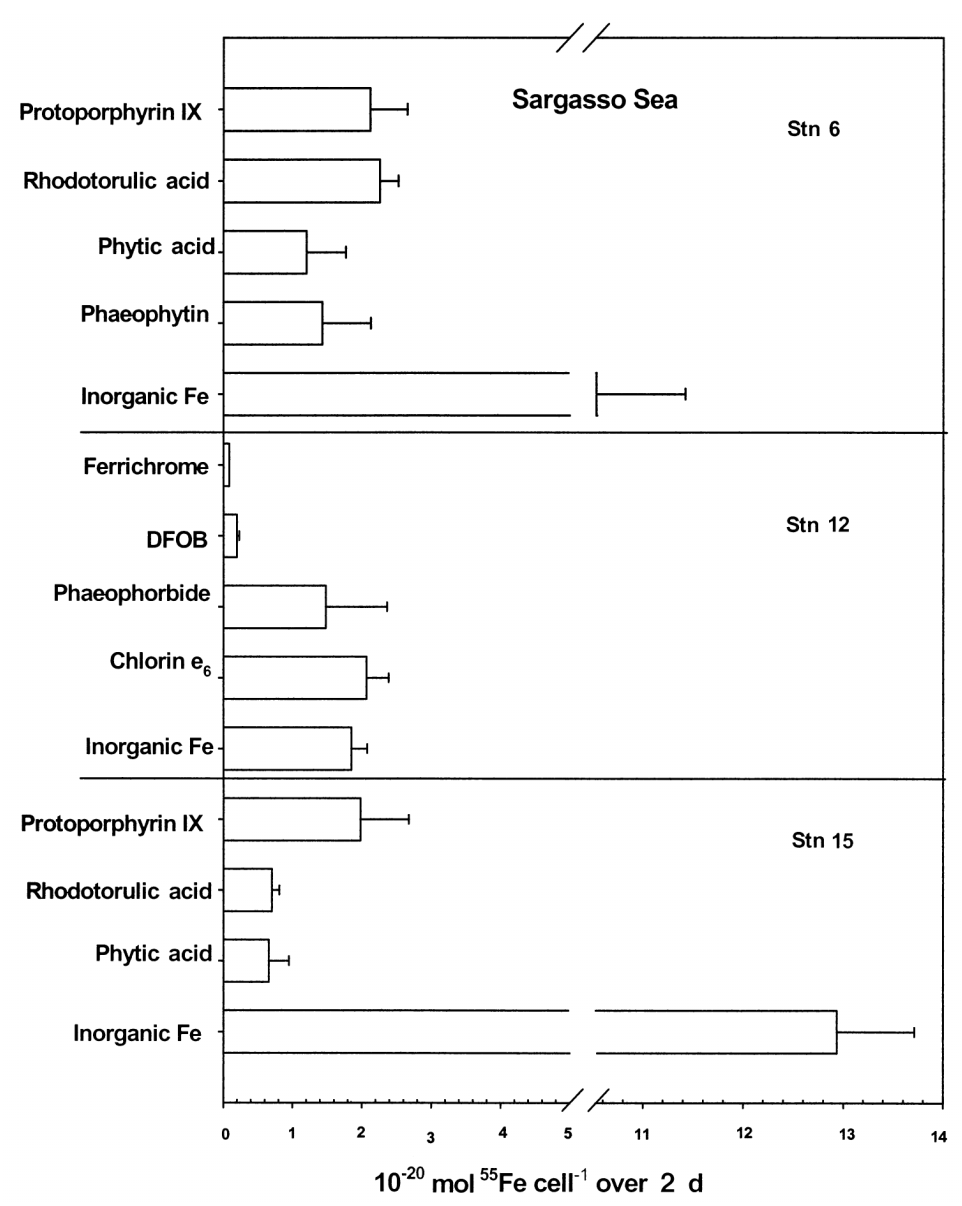

Fig. 7. Uptake of ligand-complexed $\mathrm{Fe}$ and Fe added in inorganic form expressed as mol Fe cell ${ }^{-1}$ over a $2 \mathrm{~d}$ period by the natural bacterioplankton community at 3 stations in the Sargasso Sea. Values and error bars represent the means $+\mathrm{SD}$ of 3 replicate bottles

The field results from the Sargasso Sea were similar, in that the natural bacterioplankton at 2 out of the 3 stations had much higher uptake rates in the inorganic treatments than in the model ligand treatments. The bacterioplankton of the California upwelling, however, were able to utilize Fe bound to our model ligands just as efficiently, if not more so, as in the treatment where Fe was added in inorganic form. The fact that the bacterial community utilizes the same ligand with very different efficiencies at different stations suggests that factors other than just ligand structure have a large effect on uptake. For instance, the growth rates, history, and degree of limitation by carbon or other nutrients may affect whole community uptake rates. A community growing at very low ambient Fe concentrations would also likely have an elevated uptake rate. Because different bacterial taxa may have differing abilities to use particular organic Fe sources, community composition is also undoubt- edly a factor. These last 2 suggestions are supported by the results of our lab experiments comparing Fe-stressed and Fe-replete gamma and alpha proteobacteria.

An apparent preference for Fe added in inorganic form does not necessarily imply that the iron was taken up in this form. In the field experiments, the added inorganic Fe would have rapidly equilibrated with excess natural ligands (Witter et al. 2000). These results could therefore indicate that naturally-occurring ligand complexes are sometimes more available to bacteria than our model ligand complexes. In the laboratory experiments the seawater was first UV-oxidized to remove natural ligands, but it is possible that uptake of the 'inorganic' Fe was in fact mediated by ligands such as siderophores produced in vitro by the cultured bacteria themselves. Further experiments examining endogenous ligand production would be needed to test this suggestion.

Although we do not know the chemical form of Fe actually assimilated by the bacteria in our 'inorganic' treatments, these results do suggest that both alpha and gamma proteobacteria should be able to efficiently access new Fe inputs entering the ocean from inorganic sources such as dust deposition. Although little is known about direct or indirect Fe effects on bacterial community structure, shipboard experiments in which Fe was added to HNLC communities in inorganic form showed increases in the relative abundance of several gamma and alpha proteobacterial taxa (Hutchins et al. 2001).

\section{Fe-limited versus Fe-replete uptake rates}

In all 4 culture experiments with Vibrio natriegens and IRI-16, the Fe-limited bacteria had higher cell-normalized Fe uptake rates than the Fe-replete bacteria. This was expected, as Fe-limited phytoplankton have higher uptake rates than phytoplankton grown under Fe-replete conditions (Wilhelm \& Trick 1994, Sunda \& Huntsman 1995). Under conditions of Fe stress, uptake systems for organically-bound Fe acquisition are activated, as in the cyanobacterium Synechococcus spp. Siderophores and cell-surface receptor proteins for both endogenous and exogenous ligands may be produced to bring Fe into the cell, and ligand/ligand exchange mechanisms may be involved (Wilhelm \& Trick 1994). Similar mechanisms are likely to operate in heterotrophic bacteria, such as the ones we examined here. 


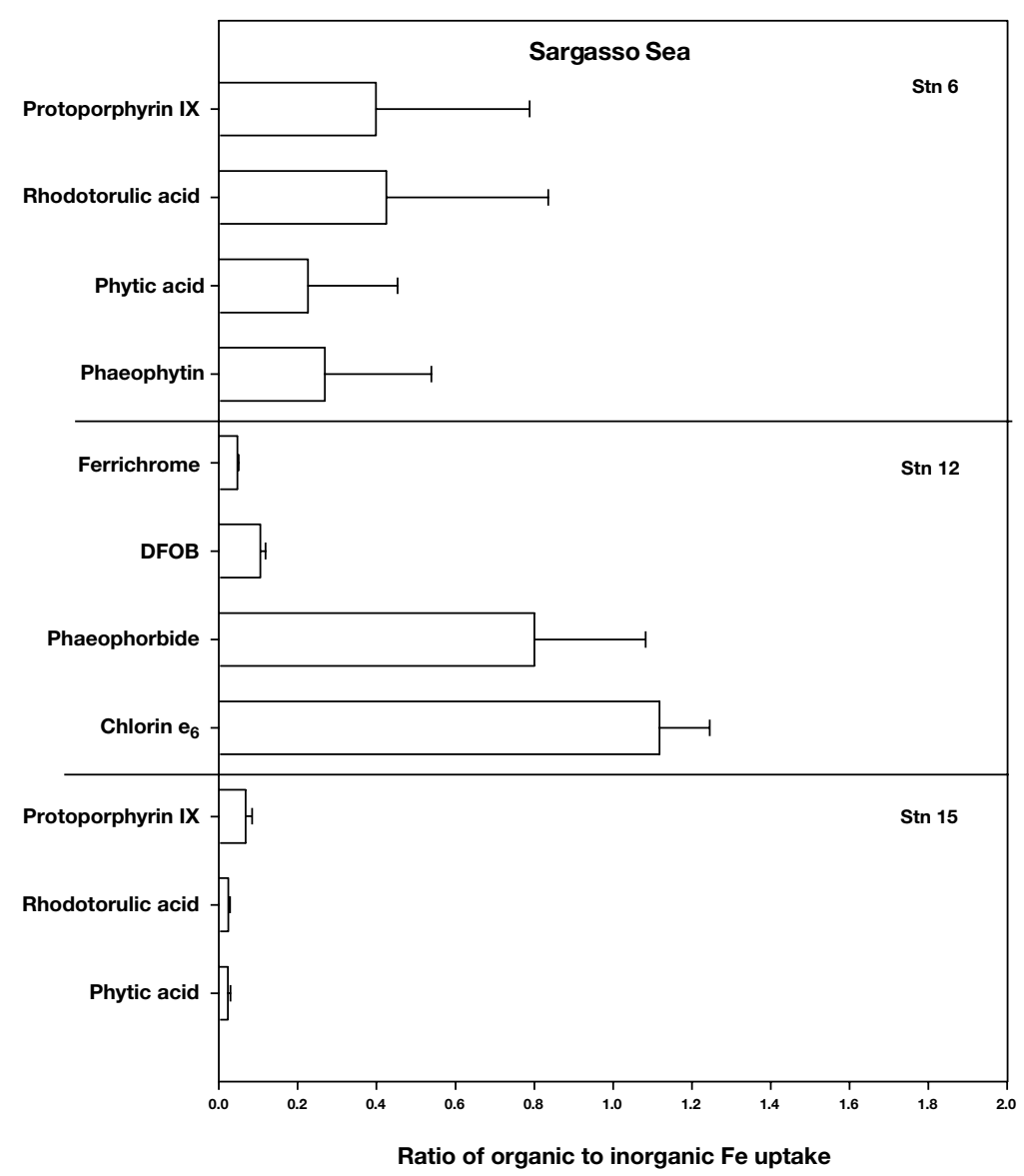

Fig. 8. Ligand-complexed Fe uptake normalized to inorganic Fe uptake in the Sargasso Sea. Relative uptake is expressed as a decimal fraction of inorganic Fe uptake. Error bars were calculated by propagation of error
Pacific (C. Trick et al. unpubl.), also suggests that rhodotorulic acid is one of the most bioavailable of the model ligands that have been examined. V. natriegens had only limited access to porphyrin bound Fe. If this isolate relies on recognition of exogenous functional groups, porphyrins may not be among the structures recognized (Hutchins et al. 1999). Fe bound to the other non-siderophore ligand, phytic acid, was however utilized by $V$. natriegens to a noteworthy degree.

In contrast to Vibrio natriegens, IRI-16 had very little success at obtaining any of the organically bound Fe. The high uptake rates in the Fe-deplete 'inorganic' treatments, however, again suggest activation of a high-affinity uptake system such as siderophores. Perhaps this alpha proteobacterium lacks the exogenous siderophore receptors that seem to be present in $V$. natriegens (Granger \& Price 1999, this study) and Synechococcus spp. (Hutchins et al. 1999). Another possibility is that the siderophores produced by IRI-16 possess an unusual or unique functional group that was not included in the model ligands we used, such as the $\beta$-hydroxy-aspartate found in alterobactin A (Reid et al. 1993) or carboxylates such as in rhizobactin (Hofte 1993). If so, catecholate, hydroxamate and porphyrin groups may not be recognizable by the bacterium's uptake system.

We cannot make broad generalizations about the influence of organic Fe complexation on competitive success in natural communities, because we only examined one species from 2 subclasses. The ability to use various organic Fe complexes is likely to be highly variable at the genus or even species level (Guan et al. 2001), and extensive further experimentation is needed to examine the effects of ligand structure to a broad range of marine bacterial groups. Our results, however, show that utilization of $\mathrm{Fe}$ bound to organic ligands by Vibrio natriegens and IRI-16 varies greatly, with possible implications for competition and bacterial community structure. Bacteria with Fe uptake capabilities similar to $V$. natriegens should have an advantage in regions where Fe is mostly bound to catecholate and hydroxamate ligands. For instance, Cottrell \& Kirchman (2000) found that gamma proteobacteria were more abundant than alpha proteobacteria at most stations in the California upwelling, an area where Macrellis et al. (2001) also found high concentrations of dissolved hydroxamate and catecholate ligands.

Our laboratory experiments were designed to measure short-term $(2 \mathrm{~h})$ uptake rates from the model 
ligand complexes. Short uptake periods allow normalization of rates to cell numbers, which is not possible when extensive growth occurs during longer experiments. They also minimize the potential for negative feedback regulation of Fe uptake due to cell satiation or saturation of uptake sites. However, it is possible that longer experiments would allow induction of ligand-specific uptake systems and result in higher uptake rates of some forms of complexed Fe. Our results should therefore be considered as near-instantaneous rates, rather than rates of bacteria acclimated to growth in the presence of the model ligands.

The apparent complexity of the relationship between ligand structure and Fe availability to the bacterial community is evident by the results of our field experiments. The hypothesis that prokaryotes prefer siderophore-chelated Fe was not entirely supported by the results from either the Sargasso Sea or the California upwelling. In some cases, bacterioplankton communities utilized porphyrin-bound Fe with an efficiency equal to or greater than utilization of siderophore-bound Fe. Relative uptake of porphyrin- and siderophore-bound $\mathrm{Fe}$ also changed considerably from station to station, with no clear pattern. These highly variable results suggest that ligand structure does not have a simple relationship with bioavailability to the community as a whole. The high uptake rates in the 'inorganic' treatments relative to the ligand treatments at several stations are similar to our laboratory results with IRI-16. Bacterioplankton at these stations could be obtaining Fe rapidly from excess inorganic uncomplexed ${ }^{55} \mathrm{Fe}$, from ${ }^{55} \mathrm{Fe}$ bound to the natural ligands, or from an unknown siderophore produced during the incubations, perhaps one with a functional group that was not considered in these experiments.

It is evident from our results that prokaryotes cannot always utilize $\mathrm{Fe}$ bound to a siderophore and can sometimes obtain iron successfully from porphyrins. Iron uptake characteristics may depend on specifics of community structure, and Fe demand by the bacterioplankton could also vary at each station, depending on their unknown growth history prior to our experiments. These results point out the need for further field research coupling iron bioavailability studies with indepth community composition analyses, to obtain a comprehensive understanding of the role that $\mathrm{Fe}$ ligand structure plays in the cycling of Fe by heterotrophic bacteria in the oceans.

Acknowledgements. We thank K. Bruland, M. Cottrell, G. Luther, G. Smith, D. Weeks, A. Witter, and the captains and crews of the RV 'Cape Henlopen' and RV 'Pt. Sur'. This work was supported by NSF grants OCE 9730334 to D.A.H. and D.L.K., and OCE 9811062 to D.A.H.

\section{LITERATURE CITED}

Berges JA, Falkowski PG (1998) Physiological stress and cell death in marine phytoplankton: induction of proteases in response to nitrogen or light limitation. Limnol Oceanogr 43:129-135

Boyd PW, Watson A, Law CS, Abraham E and 31 others (2000) A mesoscale phytoplankton bloom in the polar Southern Ocean stimulated by iron fertilization. Nature 407: 695-702

Bruland KW, Rue EL, Smith GJ (2001) Fe and macronutrients in California coastal upwelling regimes: implications for diatom blooms. Limnol Oceanogr 46:1661-1674

Butler A (1998) Acquisition and utilization of transition metal ions by marine organisms. Science 281:207-209

Church MT, Hutchins DA, Ducklow HW (2000) Limitation of bacterial growth in dissolved organic matter and iron in the southern ocean. Appl Environ Microbiol 66: 455-466

Coale KH, Johnson KS, Fitzwater SE, Gordon RM and 11 others (1996) A massive phytoplankton bloom induced by an ecosystem-scale iron fertilization experiment in the equatorial Pacific Ocean. Nature 383: 495-501

Cochlan WP (2001) Heterotrophic bacterial processes in response to a mesoscale iron enrichment in the equatorial Pacific. Limnol Oceanogr 46:428-435

Cottrell MT, Kirchman DL (2000) Community composition of marine bacterioplankton determined by 16s rRNA gene clone libraries and fluorescence in-situ hybridization. Appl Environ Microbiol 66: 5116-5122

De Baar HJW, Dejong JTM, Baker DCE, Loscher BM, Veth C, Bathmann U, Smatacek V (1995) Importance of iron for plankton blooms and carbon dioxide draw down in the Southern Ocean. Nature 373:412-415

Delong EF, Franks DG, Alldredge AL (1993) Phylogenetic diversity of aggregate-attached versus free-living bacteria marine bacterial assemblages. Limnol Oceanogr 38: 924-934

Donat JR, Bruland KW (1988) Direct determination of dissolved cobalt and nickel in seawater by differential pulse cathodic stripping voltammetry preceded by adsorptive collection of cyclohexane-1,2-dione dioxime complexes. Anal Chem 60:240-244

Fuhrman J, Sleeter T, Carlson C, Proctor L (1989) Dominance of bacterial biomass in the Sargasso Sea and its ecological implications. Mar Ecol Prog Ser 57:207-217

Fuhrman J, McCallum K, Davis A (1993) Phylogenetic diversity of subsurface marine microbial communities from the Atlantic and Pacific oceans. Appl Environ Microbiol 59: 1294-1302

Geider RJ, LaRoche J (1994) The role of iron in phytoplankton photosynthesis, and the potential for iron-limitation of primary productivity in the sea. Photosynth Res 39:275-301

Giovanonni SJ, Britschgi TB, Moyer CM, Field KG (1990) Genetic diversity in Sargasso Sea bacterioplankton. Nature 345:60-63

Gledhill M, van den Berg CMG (1994) Determination of complexation of iron(III) with natural organic complexing ligands in seawater using cathodic stripping voltammetry. Mar Chem 47:41-54

Gobler CJ, Hutchins DA, Fisher NS, Cosper EM, SanudoWilhelmy SA (1997) Elemental release and bioavailability following viral lysis of a marine chrysophyte. Limnol Oceanogr 42:1492-1504

Granger J, Price NM (1999) The importance of siderophores in iron nutrition of heterotrophic marine bacteria. Limnol Oceanogr 44: 541-555

Guan LL, Kanoh K, Kamino K (2001) Effect of exogenous 
siderophores on iron uptake activity of marine bacteria under iron-limited conditions. Appl Environ Microbiol 67: $1710-1717$

Haygood MG, Holt PD, Butler A (1993) Aerobactin production by a planktonic marine Vibrio sp. Limnol Oceanogr 38: 1091-1097

Head EJH, Harris LR (1994) Feeding selectivity by copepods grazing on natural mixtures of phytoplankton determined by HPLC analysis of pigments. Mar Ecol Prog Ser 110: $75-83$

Hobbie JE, Daley RJ, Jasper S (1977) Use of nucleopore filters for counting bacteria by fluorescence microscopy. Appl Environ Microbiol 33:1225-1228

Hofte M (1993) Classes of microbial siderophores. In: Barton L, Hemming B (eds) Iron chelation in plants and soil microorganisms. Academic Press, San Diego, p 3-26

Hudson RJM, Morel FMM (1989) Distinguishing between extra- and intracellular iron in marine phytoplankton. Limnol Oceanogr 34:1113-1120

Hutchins DA, Bruland KW (1994) Grazer mediated regeneration and assimilation of $\mathrm{Fe} \mathrm{Zn}$, and $\mathrm{Mn}$ from planktonic prey. Mar Ecol Prog Ser 110:259-269

Hutchins DA, Bruland KW (1998) Iron-limited diatom growth and Si:N uptake ratios in a coastal upwelling regime. Nature 393:561-564

Hutchins DA, DiTullio GR, Zhang Y, Bruland KW (1998) An iron limitation mosaic in the California upwelling regime. Limnol Oceanogr 43:1037-1054

Hutchins DA, Witter AW, Butler A, Luther GW (1999) Competition among marine phytoplankton for different chelated iron species. Nature 400:858-861

Hutchins DA, Campbell B, Cottrell M, Takeda S, Cary SC (2001) Response of marine bacterial community structure to iron additions in three iron-limited regimes. Limnol Oceanogr 46:1535-1545

Keller MD, Bellows WK, Guillard RRL (1988) Microwave treatment for sterilization of phytoplankton culture media. J Exp Mar Biol Ecol 117: 279-283

Kirchman DL, Meon B, Cottrell MT, Hutchins DA, Weeks D, Bruland KW (2000) Carbon versus Fe limitation of bacterial growth in the California upwelling regime. Limnol Oceanogr 45:1681-1688

Lewis BL, Holt PD, Taylor SW, Wilhelm SW, Trick CG, Butler A, Luther GW (1995) Voltammetric estimation of iron(III) thermodynamic stability constants for catecholate siderophores isolated from marine bacteria and cyanobacteria. Mar Chem 50:179-188

Macrellis HM, Trick CG, Rue EL, Smith G, Bruland KW (2001) Collection and detection of natural iron-binding ligands from seawater. Mar Chem 76:175-187

Martin JH, Fitzwater SE (1988) Iron deficiency limits phytoplankton growth in the north-east Pacific subarctic. Nature 331:341-343

Martin JH, Gordon RM (1988) Northeast Pacific iron distributions in relation to phytoplankton productivity. Deep-Sea Res 35:177-196

Martinez JS, Haygood MG, Butler A (2001) Identification of a natural desferrioxamine siderophore produced by a marine bacterium. Limnol Oceanogr 46:420-424

Editorial responsibility: James Hollibaugh, Athens, Georgia, USA
Pakulski JD, Coffin RB, Kelley CA, Holder SL, Downer R, Aas P, Lyons MM, Jeffrey WH (1996) Iron stimulation of Antarctic bacteria. Nature 383:133-134

Parsons TR, Maita Y, Lalli CM (1984) A manual of chemical and biological methods for seawater analysis. Pergamon Press, New York, p 104-110

Price NM, Harrison GI, Hering JG, Hudson RJ, Nirel PMV, Palenik B, Morel FMM (1989) Preparation and chemistry of the artificial algal culture medium Aquil Biol Oceanogr 6:443-461

Price NM, Ahner BA, Morel FM (1991) Iron and nitrogen nutrition of equatorial Pacific plankton. Deep-Sea Res I 38: 1361-1378

Price NM, Ahner BA, Morel FMM (1994) The equatorial Pacific Ocean: grazer- controlled phytoplankton populations in an iron limited ecosystem. Limnol Oceanogr 39: 520-534

Reid RT, Live DH, Faulkner DJ, Butler A (1993) A siderophore from a marine bacterium with an exceptional ferric ion affinity constant. Nature 366:455-458

Rue EL, Bruland KW (1995) Complexation of iron(III) by natural organic ligands in the Central North Pacific as determined by a new competitive ligand equilibrium/ adsorptive cathodic stripping voltammetric method. Mar Chem 50:117-138

Schmidt M, Hutchins DA (1999) Size-fractionated biological iron and carbon uptake along a coastal to offshore transect in the NE Pacific. Deep-Sea Res II 46:2487-2503

Sunda WG, Huntsman SA (1995) Iron uptake and growth limitation in oceanic and coastal phytoplankton. Mar Chem 50:189-206

Suzumura M, Kamatani A (1995) Origin and distribution of inositol hexaphosphate in estuarine and coastal sediments. Limnol Oceanogr 40:1254-1261

Wilhelm SW, Trick CG (1994) Iron limited growth of cyanobacteria: multiple siderophore production is a common response. Limnol Oceanogr 39:1979-1984

Wilhelm SW, Maxwell DP, Trick CG (1996) Growth, iron requirements, and siderophore production in ironlimited Synechococcus PCC 7002. Limnol Oceanogr 41: 89-97

Wilhelm SW, MacAuley K, Trick CG (1998) Evidence for the importance of catechol-type siderophores in the ironlimited growth of a cyanobacterium. Limnol Oceanogr 43: 992-997

Witter A, Hutchins DA, Butler A, Luther GW (2000) Determination of conditional stability constants and kinetic constants for strong model Fe-binding ligands in seawater. Mar Chem 69:1-17

Wu J, Luther GW (1994) Size-fractionated iron concentrations in the water column of the western North Atlantic Ocean. Limnol Oceanogr 39:1119-1129

Wu J, Luther GW (1995) Complexation of Fe(III) by natural organic ligands in the northwest Atlantic Ocean by a competitive ligand method and a kinetic approach. Mar Chem 40:159-177

Wu J, Luther GW (1996) Spatial and temporal distribution of iron in the surface water of the northwestern Atlantic Ocean. Geochim Cosmochim Acta 60:2729-2741

Submitted: June 19, 2002; Accepted: November 13, 2002

Proofs received from author(s): March 24, 2003 